Supporting Information for:

\title{
$\mathrm{P}_{450} / \mathrm{NADPH} / \mathrm{O}_{2}$ and $\mathrm{P}_{450} / \mathrm{PhlO}-$ Catalyzed $\mathrm{N}$-Dealkylations are Mechanistically Distinct
}

\author{
Mehul N. Bhakta ${ }^{1}$, Paul F. Hollenberg ${ }^{2}$, Kandatege Wimalasena ${ }^{1 *}$ \\ ${ }^{1}$ Department of Chemistry, Wichita State University, Wichita, KS 67260-0051; ${ }^{2}$ Department of \\ Pharmacology, University of Michigan Medical School, Ann Arbor, MI 48109-0632 \\ E-mail: : kandatege.wimalasena@wichita.edu
}

\section{List of Content:}

\section{S1-S5. Experimental Section.}

S6-S12 GC/MS traces of $\mathrm{P}_{450} / \mathrm{NADPH}, \mathrm{P}_{450} / \mathrm{PhIO}$ and HRP catalyzed oxidation of 1 under various reaction conditions. The product distribution patterns of $\mathbf{2} \& \mathbf{3}$ are similar to that of $\mathbf{1}$ and their GC and GC/MS analyses are not shown.

S6-S12 Figure 1.1 GC/MS analyses of the CPY2B1/NADPH/O $/ 2$ reaction products without (Panel A) and with cyanide (Panel B).

Figure 1.2 GC/MS analyses of the $\mathrm{CPY} 2 \mathrm{~B} 1 / \mathrm{PhIO} / 1$ reaction products without (Panel A) and with cyanide (Panel B).

Figure 1.3 GC/MS analyses of the $\mathrm{HRP} / \mathrm{H}_{2} \mathrm{O}_{2} / \mathbf{1}$ reaction products without (Panel A) and with cyanide (Panel B).

Figure 1.4 Mass Spectra of 1

Figure 1.5 Mass Spectra of 1a

Figure 1.6 Mass Spectra of $\mathbf{1 b}$

Figure 1.7 Mass Spectra of 1c 


\section{Experimental Section}

Materials. All moisture sensitive reactions were carried out in oven-dried glassware under a nitrogen atmosphere. Tetrahydrofuran (THF) was dried over sodium and distilled under a nitrogen atmosphere. Horseradish peroxidase (HRP) $(\mathrm{EC}$ 1.11.1.7, RZ = 3.1) was obtained from Sigma and dissolved in $0.4 \mathrm{M}$ potassium phosphate buffer, $\mathrm{pH} 5.5$, at a concentration of 102 $\mu \mathrm{g} / \mathrm{ml}$; the working solution was stable at $4{ }^{\circ} \mathrm{C}$ for several months. Deuterated formic acid $\left(\mathrm{DCO}_{2} \mathrm{H}\right) \quad(>98 \%$ deuterium content $), \mathrm{LiAlD}_{4}$, and Borane-methyl-sulfide complex were purchased from Sigma-Aldrich. All other reagents and chemicals used were obtained from various commercial sources and were used without further purification.

Iodosylbenzene was prepared according to the method of Sharefkin and Saltzman. ${ }^{1}$ Compounds 1-5 were synthesized according to the procedure of Chaplinski and de Meijere ${ }^{2}$ using the corresponding $\mathrm{N}$-alkyl-formanilide in good yield. ${ }^{1} \mathrm{H}-,{ }^{13} \mathrm{C}$ NMR spectra were recorded on a Varian/Inova-300 spectrometer or Varian/Nicolet-400 spectrometer. All NMR spectra were recorded in $\mathrm{CDCl}_{3}$ using TMS $(0.0 \mathrm{ppm})$ as an internal standard. Proton chemical shifts $(\delta)$ are reported in parts per million (ppm) downfield from TMS. Proton-proton coupling constants are reported in hertz $(\mathrm{Hz})$ and reflect assumed first-order behavior. Carbon chemical shifts are reported in parts per million relative to internal $\mathrm{CDCl}_{3}(77.30 \mathrm{ppm})$. Gas chromatographic analyses were performed using a flame ionization detector on an Agilent 6890 series Gas Chromatograph with a $30 \mathrm{~m}$ x $0.320 \mathrm{~mm}$ carbon packed capillary column. Gas chromatography/mass spectral (GC/MS) analyses were performed using a Varian CP 3800 GC interfaced to a Varian-Saturn Model 2200 GC/MS/MS with $30 \mathrm{~m}$ x $0.25 \mathrm{~mm}$ carbon packed capillary column. 


\section{Syntheses}

\section{General Protocol (GP) for the syntheses of N-cyclopropyl-N-alkyl-p-chloroaniline.}

$p$-Chlroaniline was acetylated with acetic anhydride to afford $p$-chloroacetanilide which was reduced with 2.0 eq. of borane-methyl-sulfide complex in $\mathrm{THF}$ at $0{ }^{\circ} \mathrm{C}$. The reaction was stirred under refluxed for 2 hours and quenched by adding water and extracted with ethyl ether to afford N-ethyl-p-chloroaniline. Deuterium at the 2-ethyl-position was incorporated by reducing the acetanilide with $\mathrm{LiAlD}_{4}(>98 \%$ deuterium content $)$ in THF at $0{ }^{\circ} \mathrm{C}$. N-ethyl- $p$-chloroaniline was refluxed with 1.2 eq of formic acid ((D)HCOOH) to afford the corresponding formanilide in excellent yields. This was treated with 1.1 eq. $\mathrm{Ti}(\mathrm{OiPr})_{4}$ and 2.5 eq of ethylmagnesium chloride in freshly distilled THF. The reaction was mixed overnight, and quenched by adding saturated ammonium chloride solution. The resulting mixture was filtered and the filtrate was extracted with ethyl acetate. The combined organic layers were concentrated in vacuo and the residue was subjected to chromatography to afford the respective cyclopropyl compound in moderate yields.

\section{N-Cyclopropyl-N-isopropyl-p-chloroaniline (1).}

4-Chloro-N-isopropylformanilide (0.98 g, $5 \mathrm{mmol})$, and Ti(OiPr $)_{4}(1.5 \mathrm{~mL}, 5.4 \mathrm{mmol})$ in $25 \mathrm{~mL}$ THF was treated with ethylmagnesium chloride $(4.3 \mathrm{~mL}, 25 \%$ in THF, $12.4 \mathrm{mmol})$ according to GP to afford 40\% yield after purification over silica gel using hexane and ethyl acetate (19:1).

${ }^{1} \mathrm{H}$ NMR (400 MHz, $\left.\mathrm{CDCl}_{3}\right) \delta 7.16(\mathrm{td}, 2 \mathrm{H}, J=3.3,8.9 \mathrm{~Hz}), 6.93(\mathrm{td}, 2 \mathrm{H}, J=3.3,8.9), 3.84$ $(\mathrm{sep}, 1 \mathrm{H}, J=6.7 \mathrm{~Hz}), 2.25(\mathrm{tt}, 1 \mathrm{H}, J=3.8,6.4 \mathrm{~Hz})), 1.24(\mathrm{~d}, 6 \mathrm{H}, J=6.7 \mathrm{~Hz}), 0.81(\mathrm{~m}, 2 \mathrm{H}), 0.48$ $(\mathrm{m}, 2 \mathrm{H}) ;{ }^{13} \mathrm{C} \mathrm{NMR}\left(100 \mathrm{MHz}, \mathrm{CDCl}_{3}\right) \delta 150.24,128.47,123.52,118.89,54.88,26.17,21.05$, 9.27. $\mathrm{MS}=210(\mathrm{M}+1)$. N-Cyclopropyl-N-1,d-isopropyl-p-chloroaniline. 4-Chloro-N-2-disopropylformanilide $(0.57 \mathrm{~g}, 2.9 \mathrm{mmol})$, which was obtained by refluxing p-chloroaniline with 
2d-bromopropane, and $\mathrm{Ti}(\mathrm{OiPr})_{4}(0.91 \mathrm{~g}, 3.2 \mathrm{mmol}) 20 \mathrm{~mL}$ of THF was added ethylmagnesium chloride ( $2.5 \mathrm{~mL}, 25 \%$ in THF, $7.2 \mathrm{mmol}$ ) according to GP to afford $38 \%$ yield. ${ }^{1} \mathrm{H}$ NMR (300 $\left.\mathrm{MHz}, \mathrm{CDCl}_{3}\right) \delta 7.14(\mathrm{td}, 2 \mathrm{H}, J=3.0,9.0 \mathrm{~Hz}), 6.92(\mathrm{dt}, 2 \mathrm{H}, J=3.0,9.0 \mathrm{~Hz}), 2.52(\mathrm{tt}, 1 \mathrm{H}, J=$ 3.85, 6.6 Hz), $1.23(\mathrm{~s}, 6 \mathrm{H}), 0.78(\mathrm{~m}, 2 \mathrm{H}), 0.48(\mathrm{~m}, 2 \mathrm{H}) ;{ }^{13} \mathrm{C} \mathrm{NMR}\left(75.4 \mathrm{MHz}, \mathrm{CDCl}_{3}\right) \delta 150.39$, $128.54,123.45,119.06,54.42(\mathrm{t}), 26.57,20.939 .33 . \mathrm{MS}=211 \mathrm{~m} / \mathrm{z}$, deuterium content $>98 \%$. N-1d-Cyclopropyl-N-isopropyl-p-chloroaniline. 4-Chloro-N-isopropyl-d-formanilide (0.48 g, $2.4 \mathrm{mmol})$, and $\mathrm{Ti}(\mathrm{OiPr})_{4}(0.76 \mathrm{~g}, 2.6 \mathrm{mmol})$ in $20 \mathrm{~mL}$ of THF was added ethylmagnesium chloride ( $2.1 \mathrm{~mL}, 25 \%$ in THF, $6.1 \mathrm{mmol}$ ) according to GP to afford $39 \%$ yield. ${ }^{1} \mathrm{H}$ NMR (300 $\left.\mathrm{MHz}, \mathrm{CDCl}_{3}\right) \delta 7.14(\mathrm{td}, 2 \mathrm{H}, J=3.5,9.0 \mathrm{~Hz}), 6.92(\mathrm{dt}, 2 \mathrm{H}, J=3.3,9.0 \mathrm{~Hz}), 3.84$ (septet, $1 \mathrm{H}, J=$ $6.6 \mathrm{~Hz}), 1.24(\mathrm{~d}, 6 \mathrm{H}, J=6.6 \mathrm{~Hz}), 0.77(\mathrm{~m}, 2 \mathrm{H}), 0.48(\mathrm{~m}, 2 \mathrm{H}) ;{ }^{13} \mathrm{C} \mathrm{NMR}\left(75.4 \mathrm{MHz}, \mathrm{CDCl}_{3}\right)$ $\delta 150.44,128.53,123.48,119.12,54.87,26.17(\mathrm{t}), 21.06,9.22 . \mathrm{MS}=211 \mathrm{~m} / \mathrm{z}$, deuterium content $>98 \%$.

N-Cyclopropyl-N-ethyl-p-chloroaniline (2). 4-chloro-N-ethylformanilide (1.0 g, $5.5 \mathrm{mmol})$ and $\mathrm{Ti}(\mathrm{OiPr})_{4}(1.72 \mathrm{~g}, 6.0 \mathrm{mmol})$ were dissolved in $20 \mathrm{~mL}$ of THF, and ethyl magnesium chloride ( $4.8 \mathrm{~mL}, 25 \%$ in THF, $13.6 \mathrm{mmol}$ ) was added according to GP to afford $40 \%$ yield after purification over silica gel using hexane and ethyl acetate (9:1). ${ }^{1} \mathrm{H}$ NMR $\left(400 \mathrm{MHz}, \mathrm{CDCl}_{3}\right) \delta$ $7.14(\mathrm{td}, 2 \mathrm{H}, J=3.0,9.1 \mathrm{~Hz}), 6.87(\mathrm{dt}, 2 \mathrm{H}, J=3.0,9.1 \mathrm{~Hz}), 3.42(\mathrm{q}, 2 \mathrm{H}, J=7.2 \mathrm{~Hz}), 2.37(\mathrm{tt}$, $1 \mathrm{H}, J=3.85,6.6 \mathrm{~Hz}), 1.06(\mathrm{t}, 3 \mathrm{H}, J=6.9 \mathrm{~Hz}), 0.79(\mathrm{~m}, 2 \mathrm{H}), 0.56(\mathrm{~m}, 2 \mathrm{H}) ;{ }^{13} \mathrm{C} \mathrm{NMR}(100 \mathrm{MHz}$, $\left.\mathrm{CDCl}_{3}\right) \delta 148.14,128.94,122.24,115.70,45.70,31.20,11.65,9.21 . \quad \mathrm{MS}=195(\mathrm{M}+1)$. N-Cyclopropyl-N-(1,1)dideuterioethyl-p-chloroaniline. 4-Chloro-N-(2,2-dideuterio) ethylformamide $(1.0 \mathrm{~g}, 5.4 \mathrm{mmol})$ was treated with $\mathrm{Ti}(\mathrm{OiPr})_{4}(1.7 \mathrm{~g}, 6.0 \mathrm{mmol})$ in $20 \mathrm{~mL}$ THF and ethylmagnesium chloride $(4.8 \mathrm{~mL}, 25 \%$ in THF, $13.6 \mathrm{mmol})$ according to GP to afford $35 \%$ 
yield. ${ }^{1} \mathrm{H}$ NMR $\left(400 \mathrm{MHz}, \mathrm{CDCl}_{3}\right) \delta 7.14(\mathrm{td}, 2 \mathrm{H}, J=3.5,9.1 \mathrm{~Hz}), 6.87(\mathrm{dt}, 2 \mathrm{H}, J=3.5,9.1$ $\mathrm{Hz}), 2.37(\mathrm{tt}, 1 \mathrm{H}, J=3.85,6.6 \mathrm{~Hz}), 1.05(\mathrm{~s}, 3 \mathrm{H}), 0.79(\mathrm{~m}, 2 \mathrm{H}), 0.56(\mathrm{~m}, 2 \mathrm{H}) ;{ }^{13} \mathrm{C}$ NMR $(100$ $\left.\mathrm{MHz}, \mathrm{CDCl}_{3}\right) \delta 148.14,128.94,122.24,115.60,31.04,11.31,9.04 . \mathrm{MS}=197 \mathrm{~m} / \mathrm{z}$, deuterium content $>98 \%$. N-1,d-Cyclopropyl-N-ethyl-p-chloroaniline. 4-Chloro-N-ethyl-d-formamide $(1.0 \mathrm{~g}, 5.4 \mathrm{mmol})$ was treated with $\mathrm{Ti}(\mathrm{OiPr})_{4}(1.7 \mathrm{~g}, 6.0 \mathrm{mmol})$ in $20 \mathrm{~mL}$ THF and ethylmagnesium chloride ( $4.8 \mathrm{~mL}, 25 \%$ in THF, $13.6 \mathrm{mmol}$ ) according to GP to afford $37 \%$ yield. ${ }^{1} \mathrm{H}$ NMR (400 MHz, $\left.\mathrm{CDCl}_{3}\right) \delta 7.14(\mathrm{td}, 2 \mathrm{H}, J=3.3,9.1 \mathrm{~Hz}), 6.87(\mathrm{dt}, 2 \mathrm{H}, J=3.3,9.1 \mathrm{~Hz})$, $3.44(\mathrm{q}, 2 \mathrm{H}, J=6.9 \mathrm{~Hz}), 1.06(\mathrm{t}, 3 \mathrm{H}, J=6.9 \mathrm{~Hz}), 0.82(\mathrm{~m}, 2 \mathrm{H}), 0.58(\mathrm{~m}, 2 \mathrm{H}) ;{ }^{13} \mathrm{C}$ NMR $(100$ $\left.\mathrm{MHz}, \mathrm{CDCl}_{3}\right) \delta 148.17,128.94,122.24,115.70,45.68,11.68,9.08 . \mathrm{MS}=196 \mathrm{~m} / \mathrm{z}$, deuterium content $>98 \%$.

N-Cyclopropyl-N-benzyl-p-chloroaniline (3). A solution of 4-chloro-N-benzylformanilide (2.0 $\mathrm{g}, 8.1 \mathrm{mmol})$ and $\mathrm{Ti}(\mathrm{OiPr}) 4(2.5 \mathrm{~g}, 8.9 \mathrm{mmol})$ in $50 \mathrm{~mL}$ of THF was added ethyl magnesium chloride $(7.1 \mathrm{~mL}, 25 \%$ in THF, $20.3 \mathrm{mmol}$ ) according to GP to afford $60 \%$ yield after purification over silica gel using hexane and ethyl acetate (19:1). ${ }^{1} \mathrm{H}$ NMR (400 MHz, $\left.\mathrm{CDCl}_{3}\right) \delta$ 7.27-6.83 (m, 9H), $4.59(\mathrm{~s}, 2 \mathrm{H}), 2.59(\mathrm{tt}, 1 \mathrm{H}, \mathrm{J}=3.8,6.6 \mathrm{~Hz}), 0.84(\mathrm{~m}, 2 \mathrm{H}), 0.68(\mathrm{~m}, 2 \mathrm{H}) ;{ }^{13} \mathrm{C}$ NMR $\left(100 \mathrm{MHz}, \mathrm{CDCl}_{3}\right) \delta 148.67,139.65,128.91,128.84,127.07,126.59,122.60,115.36$, $56.45,33.11,9.27 . \mathrm{MS}=258(\mathrm{M}+1)$

Enzymatic Reactions. Enzymatic reactions with HRP were conducted in a medium containing $0.4 \mathrm{M}$ potassium phosphate, $\mathrm{pH} 5.5,52 \mathrm{nmol}$ of $\mathrm{HRP}, 4 \mathrm{mM}$ substrate in a total volume of 0.5 $\mathrm{mL}$. The reactions were initiated by adding $0.1 \mathrm{M}$ aqueous hydrogen peroxide to a final concentration of $8 \mathrm{mM}$. Reactions were terminated by the addition of $100 \mu \mathrm{L}$ of saturated 
potassium carbonate, and $500 \mu \mathrm{L}$ of ethyl acetate. The ethyl acetate extracts were dried over a gentle stream of nitrogen, and re-dissolved in methanol. Enzymatic reactions with CYP2B1 were conducted in a medium containing $50 \mathrm{mM}$ potassium phosphate buffer, $\mathrm{pH} 7.4$, containing $4 \mu \mathrm{M}$ CYP2B1 ${ }^{3} 8 \mu \mathrm{M}$ NADPH-P450-reductase and $312 \mu \mathrm{M}$ dilauroylphosphatidyl choline, 0.1 $\mathrm{mg} / \mathrm{mL}$ catalase, and $4 \mathrm{mM}$ substrate in a total volume of $250 \mu \mathrm{L}$. The reactions were initiated by adding NADPH to a final concentration of $1.2 \mathrm{mM}$ and incubated for $30 \mathrm{~min}$ at $30{ }^{\circ} \mathrm{C}$ and quenched as describe above for HRP. When $\mathrm{PhIO}$ was the oxygen donor, the reactions were carried out in a total volume of $250 \mu \mathrm{L}$ of $50 \mathrm{mM}$ potassium phosphate buffer ( $\mathrm{pH} 7.4$ ), containing $4 \mu \mathrm{M}$ CYP2B1, $312 \mu \mathrm{M}$ L- $\alpha$-dilauroyl-sn-glyceryl-3-phosphocholine, and $4 \mathrm{mM}$ substrate. The reactions were initiated by adding PhIO to a final concentration of $1.2 \mathrm{mM}$ and incubated at room temperature for a period of $2 \mathrm{~min}$. Products were extracted, identified and quantified as above for $\mathrm{NADPH} / \mathrm{O}_{2}$ supported reactions. Reaction mixtures were analyzed by GC-FID, and GC/MS and quantified based on standard curves of authentic materials.

\section{References}

1 Sharefkin, J.; Saltzman, H. Org. Syntheses Coll. 1973, 5, 658-659.

2 Chaplinski, V. ; de Meijere, A. Angew. Chem. Int. Ed. Engl. 1996, 35, 413.

3 Hanna, I. H.; Teiber, J. F.; Kokones, K. L.; Hollenberg, P. F. Arch. Biochem. Biophys. 1998, $350,324-332$. 
Figure 1.1

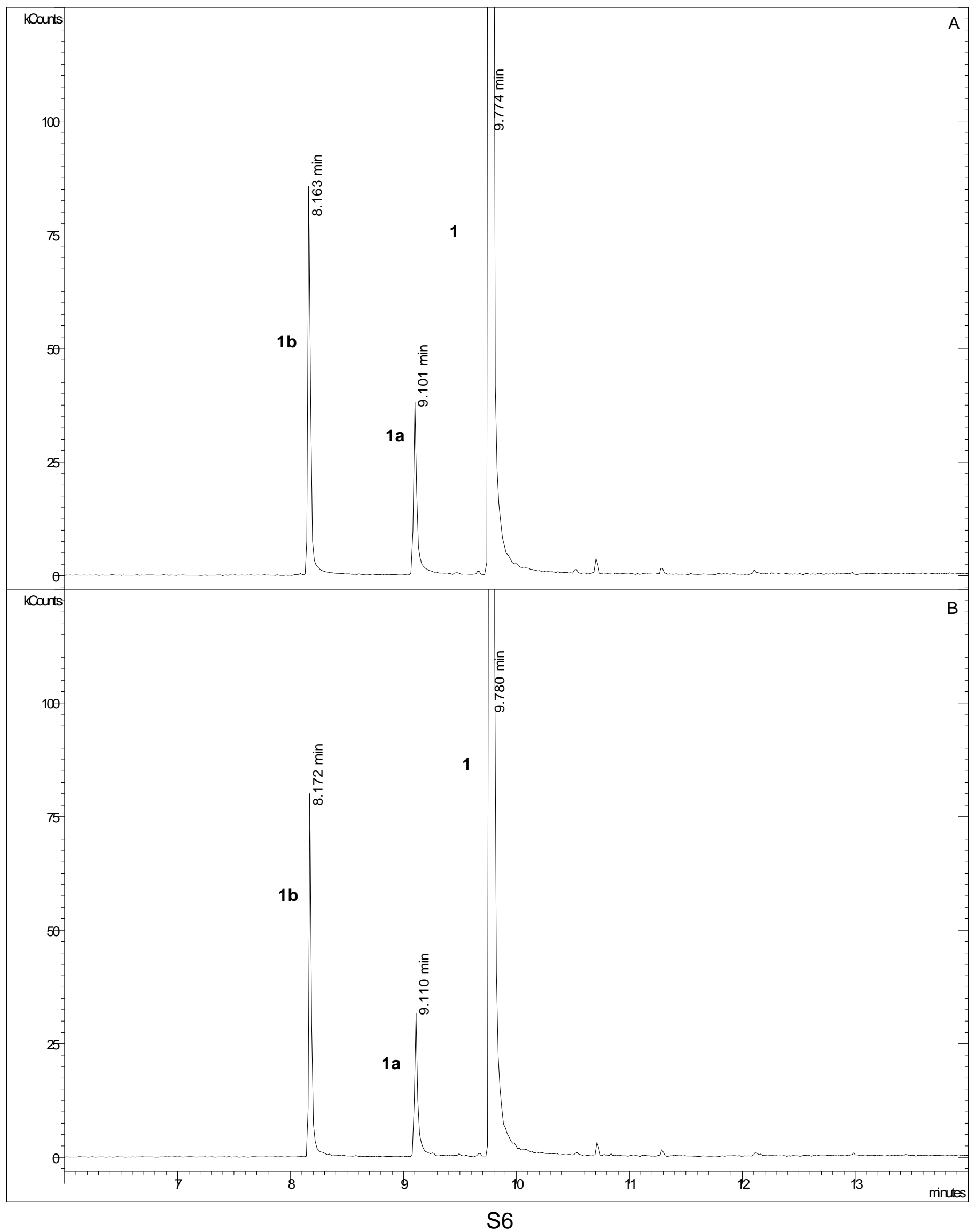


Figure 1.2

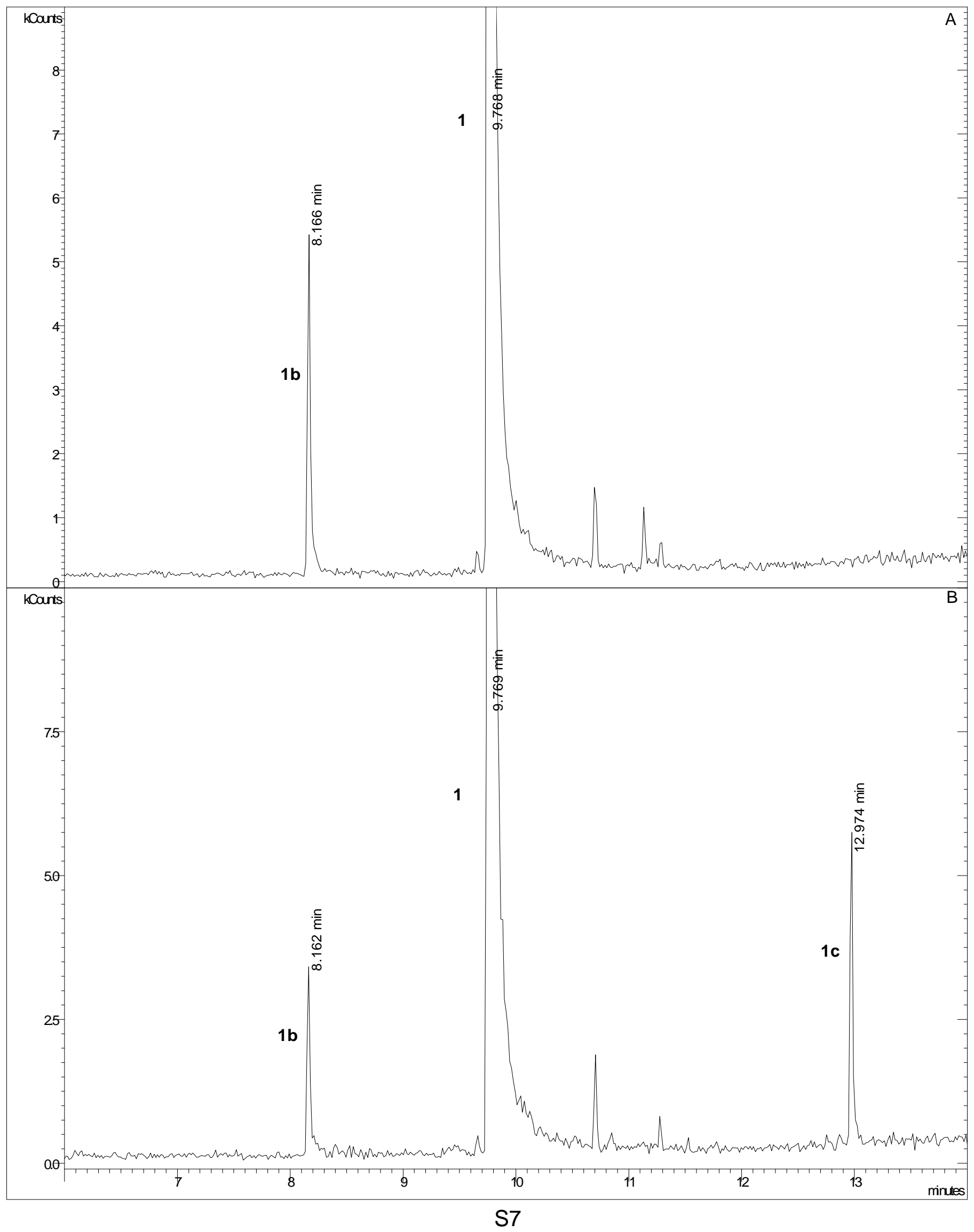


Figure 1.3

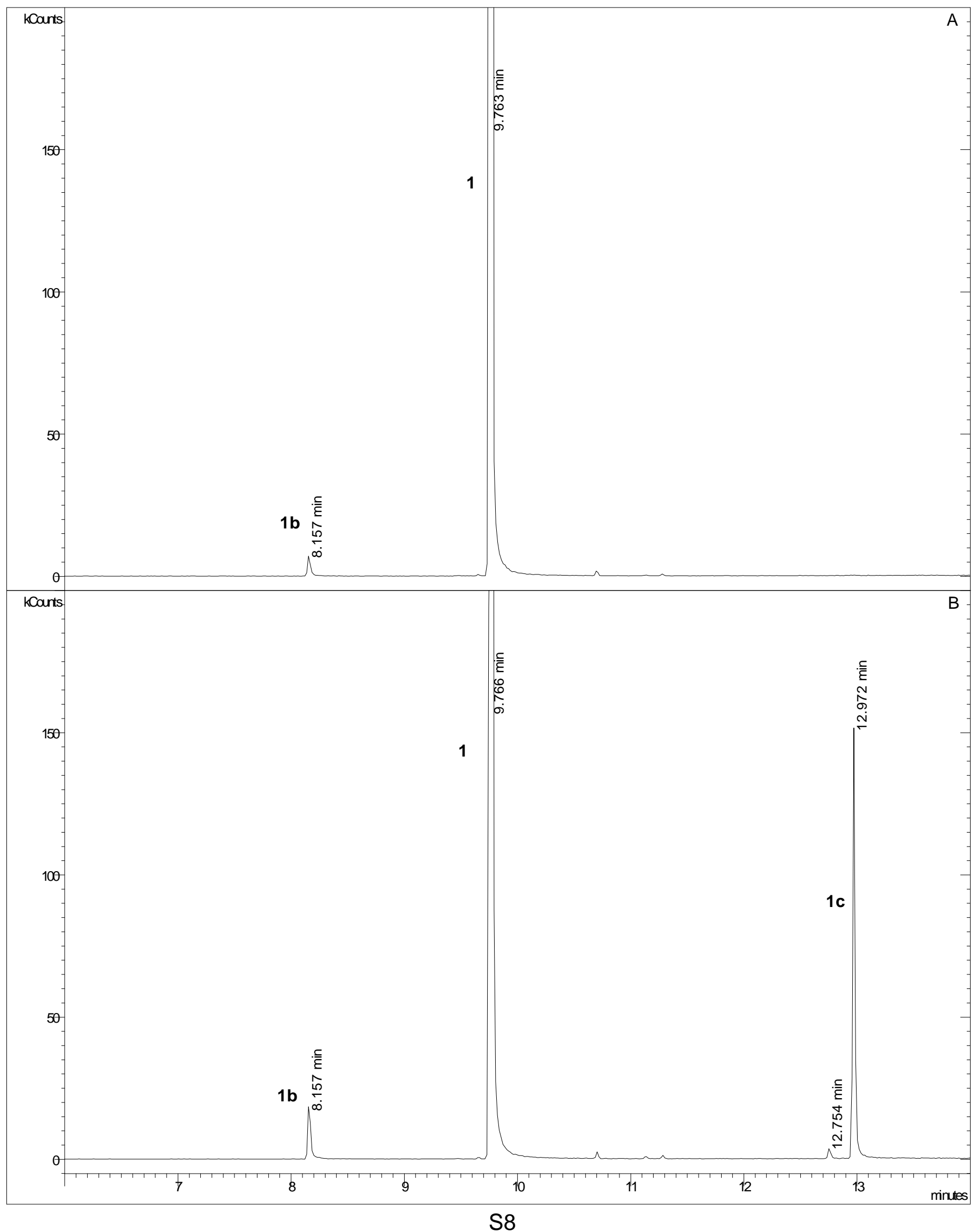


Figure 1.4

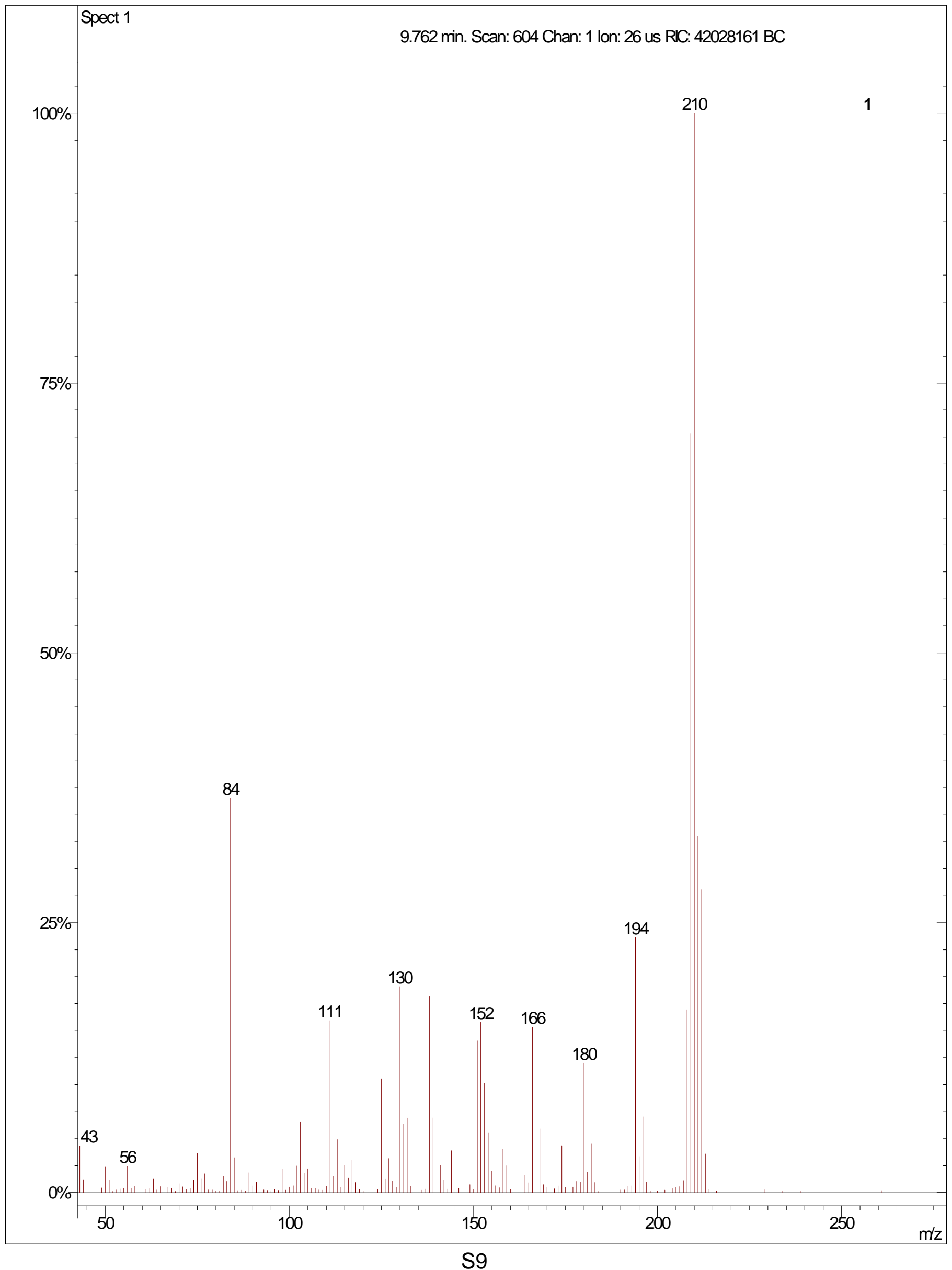


Figure 1.5

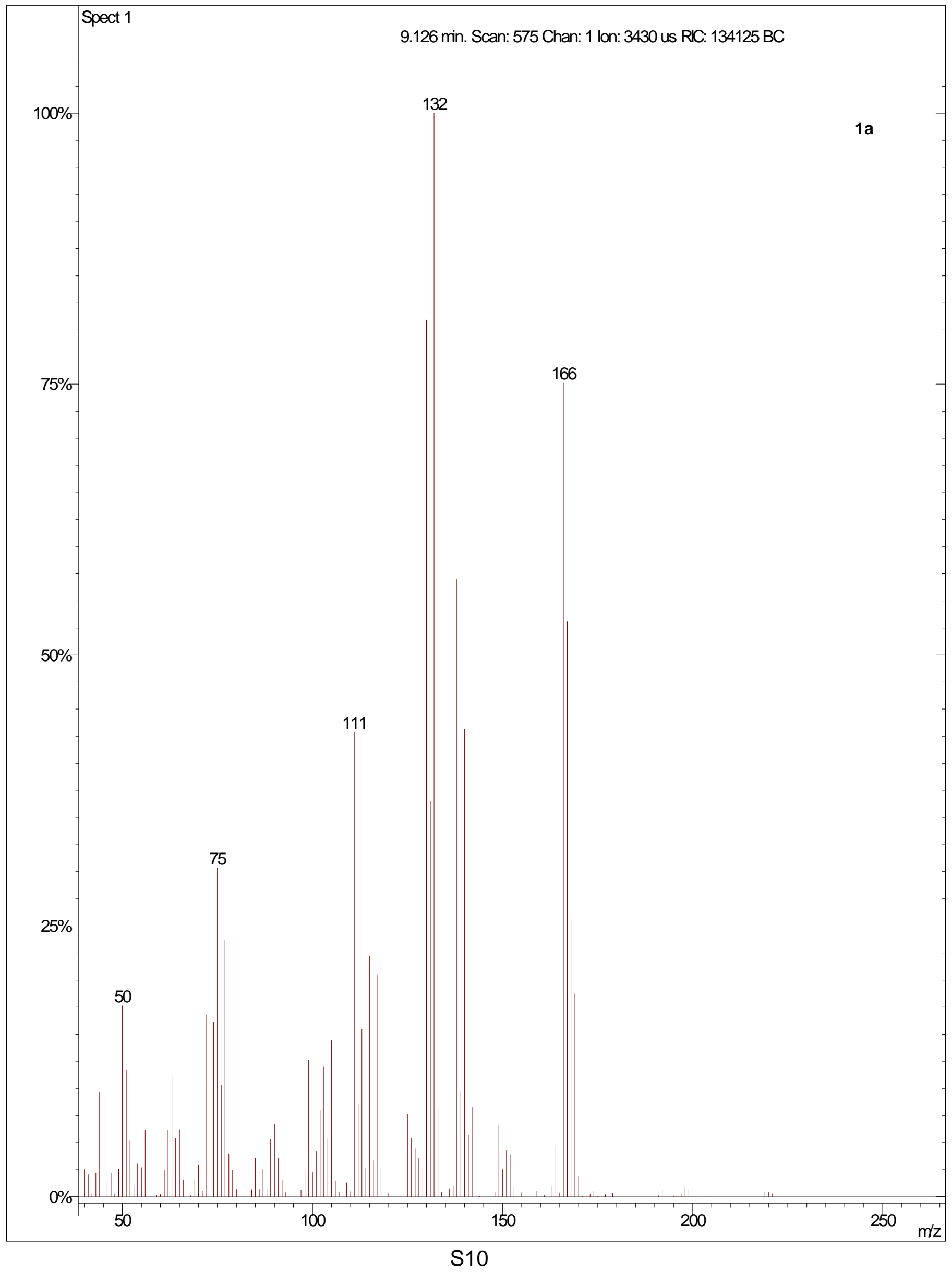


Figure 1.6

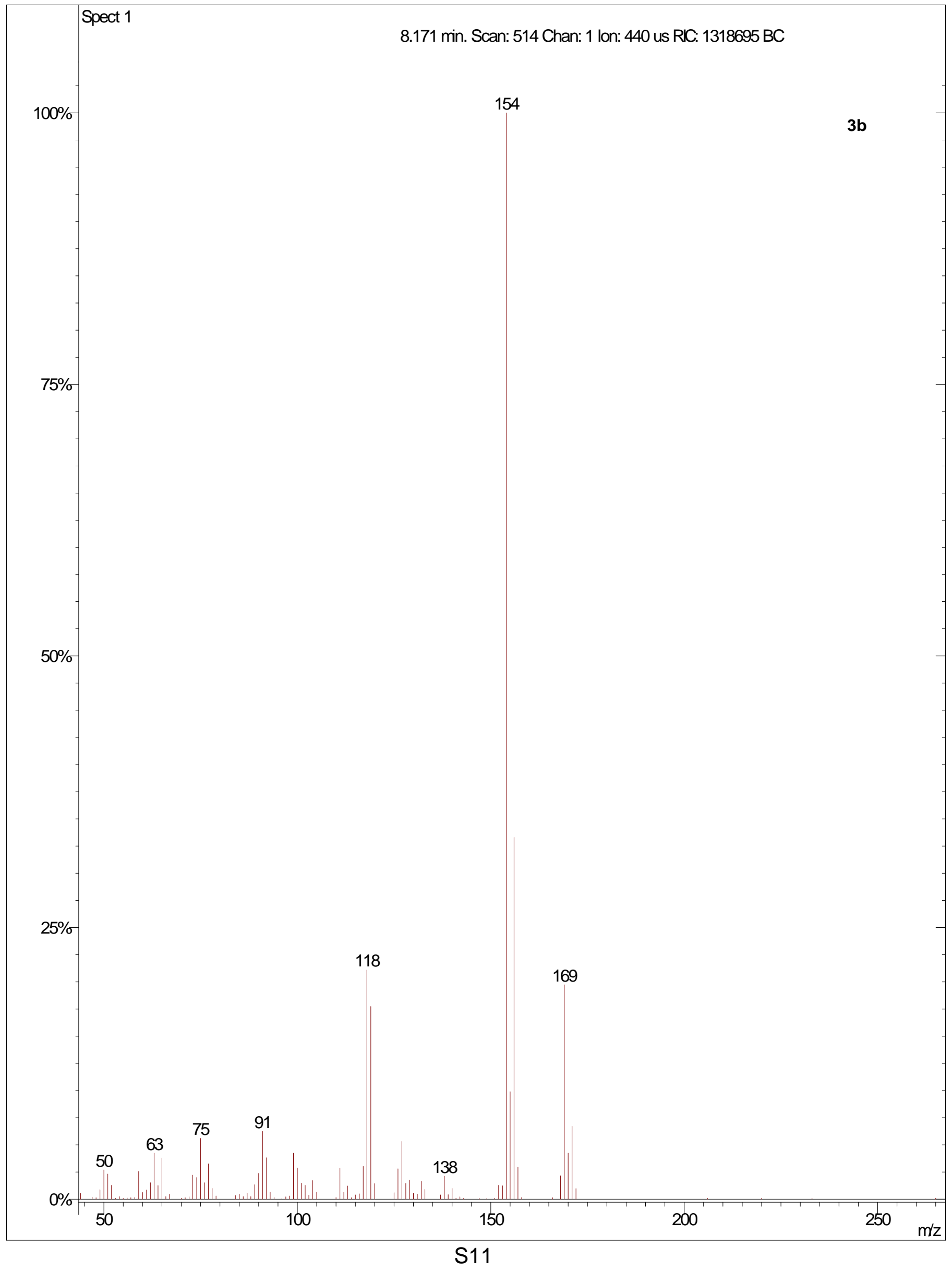


Figure 1.7

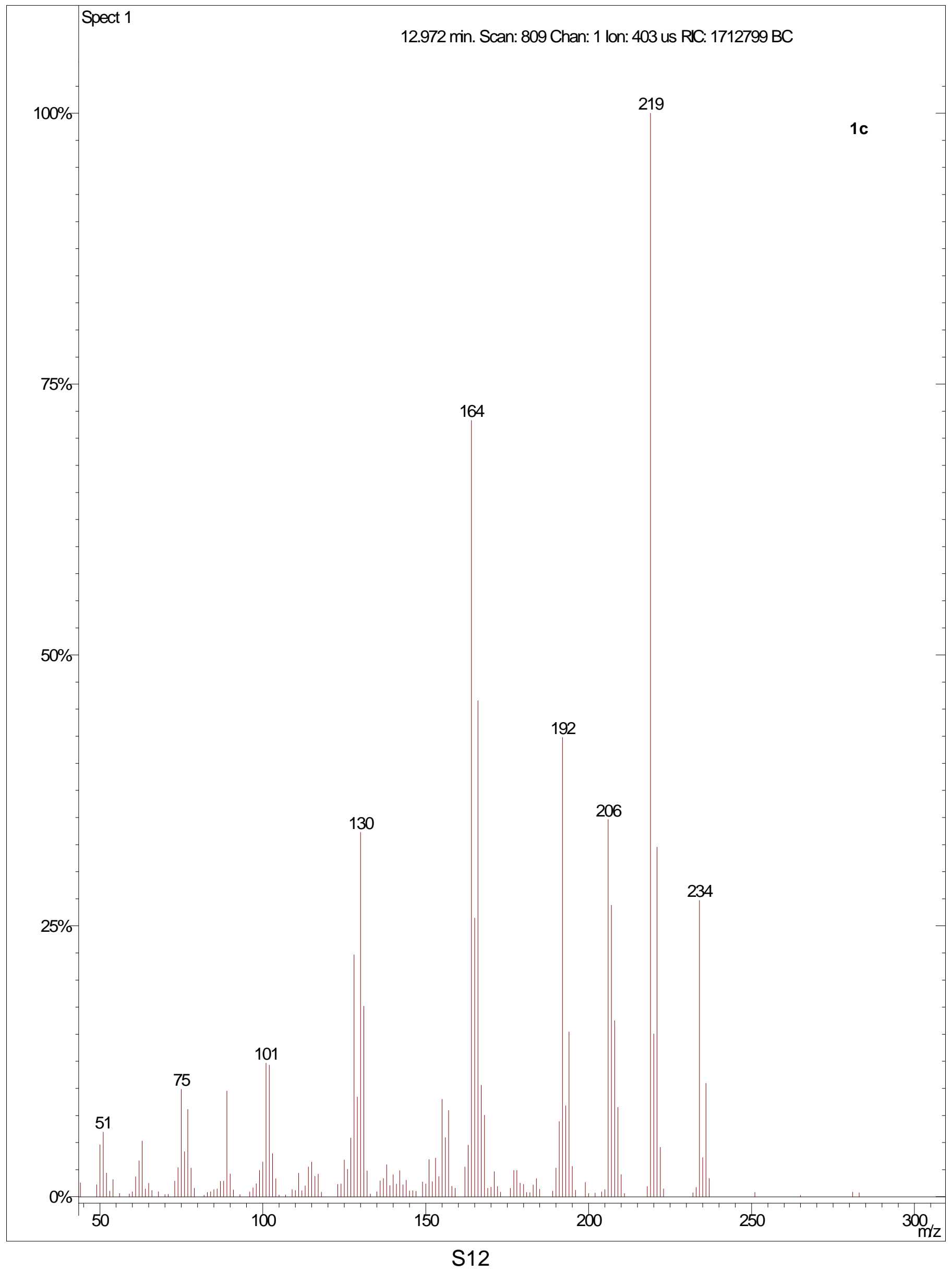

